\title{
Tanggung Jawab Hukum Dokter Terhadap Konsultasi Via Online Apabila Pasien Mengalami Kerugian
}

\author{
Adi Tio Helga Ramanda ${ }^{1}$, Agus Yudha Hernoko², Chomariyah ${ }^{3}$ \\ ${ }^{1}$ Fakultas Hukum, Universitas Hang Tuah, Jl. Arif Rahman Hakim No.150, Surabaya, 60111 \\ E-mail: aditiohelga@gmail.com \\ ${ }^{2}$ Fakultas Hukum, Universitas Hang Tuah, Jl. Arif Rahman Hakim No.150, Surabaya, 60111 \\ E-mail: magister.hukum@hangtuah.ac.id \\ ${ }^{3}$ Fakultas Hukum, Universitas Hang Tuah, Jl. Arif Rahman Hakim No.150, Surabaya, 60111 \\ E-mail: magister.hukum@hangtuah.ac.id
}

\begin{abstract}
Health is the need of every human being in living his life. Health is also very important because without good health, it will be difficult for every human being to carry out his daily activities. Entering an era of rapid development, the world is faced with the emergence of new technologies in the medical field that allow doctors to practice in a virtual space. The legal basis of online medical services as well as to analyze the legal responsibility of doctors in providing online medical services if a patient experiences a loss. Type of research is a normative juridical research and analysis of legal materials. The approach used in this study is a statutory approach and a conceptual approach. Until now, there have been no detailed regulations regarding online-based medical services, both in statutory provisions and in the provisions of the medical code of ethics. Law Number 36 of 2009 concerning Health and Law Number 29 of 2004 concerning Medical Practice have so far not been used as a reference for the implementation of medical practice using online-based medical services. Furthermore, Law Number 11 of 2008 concerning Electronic Information and Transactions also cannot be used as a reference.
\end{abstract}

Keywords_-: Legal liability; online based; medical services.

\section{PENDAHULUAN}

Layanan medis baru berupa layanan medis berbasis online pada prinsipnya memberikan pelayanan medis yang dapat dijangkau tanpa perlu tatap muka, sehingga pasien dengan jarak jauh sekalipun dapat menggunakan layanan tersebut. Dari segi penggunaannya, pada layanan medis online menggunakan aplikasi mobile yang ada di smartphone dan untuk mengaksesnya dibutuhkan jaringan internet. Jadi dapat dikatakan layanan medis online lebih mudah diakses dari segi penggunaan juga lebih praktis.

Konsultasi dokter melalui media online seharusnya tunduk terhadap Undang-Undang Nomor 11 Tahun 2008 Tentang Informasi dan Transaksi Elektronik. Para penyedia jasa konsultasi melalui sistem elektronik wajib mematuhi UU ITE. Penyedia jasa tersebut harus merancang sistem yang baik, dan aman serta dapat menjaga kerahasiaan data. Pelayanan kesehatan melalui online ini sebaiknya diatur lebih lanjut dalam peraturan khusus. Layanan medis berupa konsultasi dari konservatif ke online atau daring wajib dilindungi oleh hukum, baik perlindungan bagi dokter, penyelenggara sistem dan terlebih penting bagi pasien atau konsumen pengguna media online.

Pada pelaksanaannya, hubungan antara dokter dan pasien pada layanan medis online dilakukan dengan cara melalui internet maka seperti halnya hubungan dokter dengan pasien pada pelayanan medis konvensional, hubungan dokter dan pasien dengan menggunakan layanan medis online ini juga harus memenuhi syarat yang diatur dalam Undang-Undang Nomor 29 Tahun 2004 tentang Praktik Kedokteran. Pasal 39 mengatur bahwa praktik kedokteran dilaksanakan berdasarkan pada kesepakatan berdasarkan hubungan kepercayaan antara dokter atau dokter gigi dengan pasien dalam upaya pemeliharaan kesehatan, pencegahan penyakit, peningkatan kesehatan, pengobatan penyakit dan pemulihan kesehatan. Kesepakatan sebagaimana dimaksud merupakan upaya maksimal pengabdian profesi kedokteran yang harus dilakukan dokter dan dokter gigi dalam penyembuhan dan pemulihan kesehatan pasien sesuai dengan standar pelayanan, standar profesi, standar prosedur operasional dan kebutuhan medis pasien.

Dampak positif dari layanan medis online ialah orang dapat bertanya kapanpun dan dimanapun kepada dokter melalui HP/Smartphone tentang masalah kesehatannya. Namun, dampak negatifnya adalah bagaimana cara dokter mengetahui dengan benar kondisi tubuh psaien tersebut? Apakah batasan yang dimiliki dokter dalam memberikan pendapat mengenai masalah kesehatan tersebut? Dalam hal tanggung jawab pasien, siapa yang akan bertanggung jawab jika pasien mengalami masalah atau komplikasi selama pengobatan yang dilakukan dalam pelayanan Kesehatan berbasis online? Beberapa potensi permasalahan hukum yang dapat timbul pada layanan medis online dikemudian hari, diantaranya yaitu mengenai pemberian lisensi praktik melalui online, perlindungan data hak privasi pasien, serta tanggung gugat bila ada pihak yang mengalami kerugian. Mengingat praktik melalui online ini tidak dapat dipersamakan dengan praktik konvensional, karena pada undang-undang sebelumnya belum dapat mengakomodir layanan medis berbasis online, sehingga aturan yang digunakan harus berbeda pula. 
Berdasarkan Pasal 23 Ayat (3) Undang-Undang Nomor 36 Tahun 2009 Tentang Kesehatan mengatur bahwa dalam menyelenggarakan pelayanan kesehatan, tenaga kesehatan wajib memiliki izin dari pemerintah. Ketentuan lain yang mengatur mengenai izin tenaga kesehatan khusus profesi dokter diatur pada ketentuan Pasal 36 Undang-Undang Nomor 2009 Tahun 2004 tentang Praktik Kedokteran bahwa setiap dokter dan dokter gigi yang melakukan praktik kedokteran di Indonesia wajib memiliki surat izin praktik. Dari penjelasan pasal-pasal di atas dapat dikatakan bahwa penyelenggaran praktik kedokteran pada layanan medis online tidak sejalan dengan Undang-Undang Praktik Kedokteran yang berlaku sehingga dipertanyakan sisi legal dan etiknya karena pada layanan medis online terdapat kewajiban dokter yang tidak terpenuhi yaitu praktik yang dilakukan dokter terhadap pasien adalah praktik pada dunia nyata (fisik) dan bukan dunia maya (virtual) yang mana harus dipenuhi sesuai dengan SOP Praktik Kedokteran.

Pada layanan kesehatan umumnya, rekam medis yang digunakan dapat berbentuk kertas atau elektronik. Namun, penggunaan rekam medis dengan medium kertas tentunya tidak dapat digunakan dalam layanan konsultasi daring maupun kunjungan rumah berbasis aplikasi. Mengacu pada ketentuan Pasal 5 Peraturan Menteri Kesehatan Nomor 269 Tahun 2008 Tentang Rekam Medis yang menyatakan bahwa "setiap dokter atau dokter gigi dalam menjalankan praktik kedokteran wajib membuat rekam medis", pada hakikatnya layanan kedokteran konsultasi daring dan kunjungan rumah tidak terkecuali dan harus menggunakan rekam medik elektronik. ${ }^{1}$

Dalam penggunaan layanan medis online juga perlu diatur tentang proteksi data pasien, agar tidak mudah diakses oleh pihakpihak yang tidak berkepentingan serta memberi rasa aman terhadap setiap pengunanya. Melihat kondisi kenyataan dan implikasi permasalahan hukum yang dapat timbul pada layanan medis berbasis online maka idealnya, layanan medis berbasis online ini lebih baik hanya bersifat informasi dan edukasi serta diatur dalam hukum nasional agar dapat memberikan kepastian hukum dalam menjawab tuntutan perkembangan teknologi di bidang kedokteran. Membiarkan persoalan ini berlarut-larut akan berdampak negatif terhadap pelayanan kesehatan yang pada akhirnya akan dapat merugikan masyarakat secara keseluruhan. Disadari oleh semua pihak, bahwa dokter hanyalah manusia yang suatu saat dapat salah dan lalai sehingga pelanggaran kode etik bisa terjadi, bahkan mungkin sampai pelanggaran norma-norma hukum. ${ }^{2}$

Dengan problematika hukum tersebut diatas maka permasalahan yang dirumuskan yaitu sebagai berikut :

1. Apakah dasar hukum layanan medis berbasis online?

2. Apakah tanggung jawab hukum dokter apabila pasien mengalami kerugian sebagai akibat pelayanan medis online?

\section{METODE PENELITIAN}

\section{A. Pendekatan Masalah}

Analisa Bahan Hukum Pendekatan yang digunakan dalam penelitian ini adalah pendekatan perundang-undangan (statute approach) yaitu pendekatan yang mengkaji tentang asas-asas hukum, norma-norma hukum dan peraturan perundang-undangan serta pendekatan konseptual (conceptual approach) yaitu mengadakan identifikasi terhadap pengertian-pengertian pokok dasar dalam hukum yakni subyek hukum, hak dan kewajiban, peristiwa hukum, hubungan hukum dan obyek hukum.

\section{B. Bahan Hukum}

Bahan hukum dalam penelitian ini terdiri dari bahan hukum primer, bahan hukum sekunder dan bahan hukum tersier. Adapun bahan hukum yang dipergunakan dalam penelitian ini adalah bahan hukum primer dan bahan hukum sekunder.

\section{Bahan Hukum Primer}

Bahan hukum primer adalah bahan-bahan hukum yang mempunyai mengikat dan terdiri dari :

a. Undang-Undang Dasar Negara Republik Indonesia Tahun 1945

b. Undang - Undang Nomor 29 tahun 2004 Tentang Praktek Kedokteran

c. Undang-Undang Nomor 11 Tahun 2008 Tentang Informasi dan Transaksi Elektronik

d. Undang-Undang Nomor 36 Tahun 2009 Tentang Kesehatan

e. Peraturan Presiden Nomor 72 Tahun 2012

f. Permenkes RI Nomor 585/MEN.KES/PER/X/1989

g. Permenkes Nomor 269 Tahun 2008 Tentang Rekam Medis

\section{Bahan Hukum Sekunder}

Bahan hukum sekunder, yang memberikan penjelasan mengenai bahan hukum primer, seperti diantaranya: buku-buku, jurnal, media massa, makalah-makalah, dan lain-lain.

\footnotetext{
${ }^{1}$ Kementerian Kesehatan Republik Indonesia, 2008, Peraturan Menteri Kesehatan Nomor 269 Tahun 2008 tentang Rekam Medis.

${ }^{2}$ Marhcel Maramis, 2016, Tinjauan Yuridis Terhadap Otopsi Medikolegal Dalam Pemeriksaan Mengenai Sebab-Sebab Kematian, Jurnal Hukum Universitas Sam Ratulangi, J1., Vol.21, No.5, Januari, 2016, Medan, Hal. 86.
} 
Website : http://yustisia.unmermadiun.ac.id/index.php/yustisia

\section{Metode Pengumpulan Bahan Hukum}

Proses pengumpulan bahan hukum, peneliti menggunakan studi dokumen, yaitu mengumpulkan bahan-bahan hukum kepustakaan yang berupa peraturan perundang-undangan, buku-buku hukum, jurnal, literatur, dan kamus hukum, kamus bahasa indonesia dan buku malpraktek kedokteran. Adapun langkah- langkah pengumpulan bahan hukum meliputi: membaca, mempelajari, mengutip, menghubungkan bahan-bahan hukum dari bahan hukum primer, bahan hukum sekunder serta bahan hukum tersier sehingga menjadi satu kesatuan sehingga mudah dalam pengertian yang disampaikan.

\section{Analisa Bahan Hukum}

Metode analisis bahan hukum yang digunakan dalam penelitian ini adalah metode normative deskriptif karena penelitian ini tidak menggunakan konsep- konsep yang diukur/dinyatakan dengan angka atau rumusan statistic, maka analisis terhadap bahan hukum dilakukan dengan cara berpedoman atau berdasarkan norma/kaidah hukum (dalam arti luas, yaitu yang terdiri dari nilai hukum, azas hukum, kaidah hukum dalam arti yang sempit dan teks otoritatif atau aturan hukum), konsep hukum ataupun doktrin hukum yang terdapat pada kerangka pemikiran atau tinjauan pustaka adalah yang dipergunakan untuk menjawab permasalahan dalam penelitian ini.

\section{III.PEMBAHASAN}

\section{A. Dasar Hukum Pelayanan Kesehatan}

Pengaturan hukum bagi pelayanan kesehatan menggunakan ketentuan-ketentuan pada :

\section{Undang-Undang Nomor 36 Tahun 2009 tentang Kesehatan}

Dasar perlunya Undang-undang Pokok Kesehatan menurut Kansil: ${ }^{3}$ bahwa kesehatan rakyat merupakan salah satu modal pokok dalam rangka pertumbuhan dan kehidupan bangsa, dan mempunyai peranan penting dalam penyusunan masyrakat adil, makmur, dan sejahtera; dan karena kesejahteraan umum termasuk kesehatan, maka haruslah pelaksanaan cita-cita Bangsa Indonesia yang tercantum dalam alinea keempat Pembukaan UUD 1945, yaitu mewujudkan suatu tata masyarakat yang adil dan makmur, serta spiritual berdasarkan Pancasila. Bagi suatu masyarakat Indonesia yang adil makmur dan sejahtera, soal kesehatan merupakan suatu unsur yang sangat penting. Sehubungan dengan itu maka perlu ditetapkan suatu undangundang tentang pokok-pokok kesehatan yang sesuai dengan dasar-dasar Negara serta sesuai dengan kemajuan ilmu pengetahuan.

Dari sisi pelayanan kesehatan, UU Kesehatan 2009 lebih memberi perlindungan dan kepastian hukum baik pada pemberi layanan selaku tenaga kesehatan maupun penerima layanan kesehatan selaku pasien. Pada satu sisi, setiap orang berhak menuntut ganti rugi terhadap seseorang, tenaga kesehatan, dan atau penyelenggara kesehatan yang menimbulkan kerugian akibat kesalahan atau kelalaian dalam pelayanan kesehatan yang diterimanya. Namun disisi lain Bilamana dalam hal tenaga kesehatan diduga melakukan kelalaian dalam menjalankan profesinya maka kelalaian tersebut menurut undang-undang harus diselesaikan terlebih dahulu melalui mediasi (Pasal 29). ${ }^{4}$ Undang-Udang Nomor 29 Tahun 2004 tentang Praktik Kedokteran.

\section{Undang-Undang Nomor 29 Tahun 2004 tentang Praktik Kedokteran}

Tujuan dari adanya undang-undang mengenai praktik kedokteran ini adalah untuk memberikan perlindungan kepada pasien, mempertahankan dan meningkatkan mutu pelayanan medis yang diberikan oleh dokter dan dokter gigi, dan meberikan kepastian Hukum kepada masyarakat, dokter, dan dokter gigi sesuai dengan yang disebutkan dalam ketentuan Pasal 36 Undang-Undang Nomor 29 Tahun 2004 tentang Praktik Kedokteran.

\section{Undang-Undang Nomor 19 Tahun 2016 Tentang Perubahan Atas Undang-Undang Nomor 11 Tahun 2008 Tentang} Informasi dan Transaksi Elektronik

Jika dikaitkan dengan adanya layanan kesehatan berbasis online dengan memanfaatkan sistem elektronik dengan cara membuat website, blog, dan aplikasi berbasis online, maka dapat disimpulkan dokter dalam memberikan layanan kesehatan termasuk dalam penyelenggaraan sistem elektronik.

\section{Telemedicine}

Telemedicine adalah penggunaan teknologi informasi dan komunikasi yang digabungkan dengan kepakaran medis untuk memberikan layanan kesehatan, mulai dari konsultasi, diagnosa dan tindakan medis, tanpa terbatas ruang atau dilaksanakan dari jarak jauh. Untuk dapat berjalan dengan baik, sistem ini membutuhkan teknologi komunikasi yang memungkinkan transfer data berupa video, suara, dan gambar secara interaktif yang dilakukan secara real time dengan mengintegrasikannya ke dalam teknologi pendukung video- conference. Termasuk sebagai teknologi pendukung

\footnotetext{
${ }^{3}$ CST. Kansil, 1991, Pengantar Hukum Kesehatan Indonesia, Rineka Cipta, Jakarta, Hal. 5

${ }^{4}$ Undang-Undang Nomor 36 Tahun 2009 tentang Kesehatan
} 
telemedicine adalah teknologi pengolahan citra untuk menganalisis citra medis. ${ }^{5}$ Pengertian telemedicine disebutkan pula dalam ketentuan Pasal 1 Ayat 1 Permenkes Nomor 20 Tahun 2019 yang diartikan sebagai: "pemberian pelayanan kesehatan jarak jauh oleh profesional kesehatan dengan menggunakan teknologi informasi dan komunikasi, meliputi pertukaran informasi diagnosis, pengobatan, pencegahan penyakit dan cedera, penelitian dan evaluasi, dan pendidikan berkelanjutan penyedia layanan kesehatan untuk kepentingan peningkatan kesehatan individu dan masyarakat."

Tujuan telemedicine adalah mengusahakan tercapainya pelayanan kesehatan secara merata di seluruh populasi negara, meningkatkan kualitas pelayanan terutama untuk daerah terpencil dan penghematan biaya dibandingkan cara konvensional. Telemedicine juga ditujukan untuk mengurangi rujukan ke dokter atau pelayanan kesehatan di kota-kota besar, sarana pendidikan kedokteran dan juga untuk kasus- kasus darurat. Perluasan manfaat telemedicine bisa menjangkau daerah-daerah bencana, penerbangan jarak jauh, dan bagi wisatawan asing yang sedang berada di daerah wisata. $^{6}$

Pendapat yang sama juga dikemukan oleh Soegijardjo Soegijoko, bahwa telemedika atau telemedicine yaitu penggunaan teknologi informasi dan komunikasi termasuk pula elektronika, tele-komunikasi, komputer, informatika untuk mentransfer (mengirim dan/atau menerima) informasi kedokteran, guna meningkatkan pelayanan klinis (diagnosa dan terapi) serta pendidikan. Kata "tele" dalam bahasa Yunani berarti: jauh, pada suatu jarak, sehingga telemedika dapat diartikan sebagai pelayanan kedokteran, meskipun dipisahkan oleh jarak. ${ }^{7}$

Pemanfaatan telemedicine sangat tergantung pada tipe praktek telemedicine. Tipe atau bentuk praktek Telemedicine dapat berupa telekonsultasi, teleassistansi, teleedukasi dan telemonitoring serta telesurgery. ${ }^{8}$

Praktek kedokteran dengan menggunakan telemedicine mengandung potensi kerawanan yang dapat menyebabkan terjadi perubahan orientasi, baik dalam tata nilai maupun pemikiran karena dipengaruhi faktor-faktor politik, ekonomi, sosial, budaya, pertahanan dan keamanan serta ilmu pengetahuan dan teknologi. Perubahan orientasi tersebut akan mempengaruhi proses penyelenggaraan pembangunan kesehatan. ${ }^{9}$ Mengingat sejauh ini belum terdapat peraturan perizinan yang dibuat secara khususnya bagi fasilitas pelayanan kesehatan yang menggunakan telemedicine baik oleh pemerintah maupun pemerintah daerah. Demikian pula ketentuan tentang akreditasinya.

\section{B. Tanggung Jawab Hukum Dokter Apabila Pasien Mengalami Kerugian Akibat Pelayanan Medis}

Hukum kesehatan diperlukan untuk mengatur permasalahan kesehatan agar tercipta ketertiban dalam pergaulan hidup, hukum kesehatan adalah semua aturan hukum secara langsung berkaitan dengan pemeliharaan kesehatan dan penerapan aturan aturan pada perangkat hukum perdata, hukum pidana, selama aturan ini mengatur hubungan hukum dalam pemeliharaan kesehatan. ${ }^{10}$ Untuk tercapainya tujuan hukum kesehatan tidak luput dari peran pelayanan kesehatan, pelayanan kesehatan adalah semua tindakan yang diambil dalam rangka mencegah dan memelihara kesehatan masyarakat pada umumnya, keberhasilan upaya kesehatan tergantung pada ketersediaan sumber daya kesehatan seperti tenaga sarana prasarana serta adminitrasi dengan jumlah dan mutu yang memadai. ${ }^{11}$

Dalam pelaksanaan pelayanan medis berkaitan erat kaitannya dengan terapeutik atau dalam terjemahan dari therapeutic yang berarti dalam bidang pengobatan. Persetujuan yang terjadi antara dokter dan pasien bukan hanya di bidang pengobatan saja tetapi lebih luas, mencakup bidang diagnostik, preventif, rehabilitatif maupun promotif, maka persetujuan ini disebut pejanjian terapeutik atau transaksi terapeutik. Perjanjian Terapeutik juga disebut dengan kontrak terapeutik yang merupakan kontrak yang dikenal dalam bidang pelayanan kesehatan. Perjanjian yang dikenal dalam bidang pelayanan kesehatan yaitu perjanjian (transaksi) terapeutik. Transaksi terapeutik adalah perjanjian antara dokter dengan pasien, berupa hubungan hukum yang melahirkan hak dan kewajiban bagi kedua belah pihak. Objek dari perjanjian ini adalah berupa upaya atau terapi untuk penyembuhan pasien. ${ }^{12}$

Secara yuridis, perjanjian terapeutik diartikan sebagai hubungan hukum antara dokter dengan pasien dalam pelayanan medis secara profesional didasarkan kompetensi yang sesuai dengan keahlian dan keterampilan tertentu di bidang kesehatan. ${ }^{13}$ Transaksi terapeutik merupakan kegiatan didalam penyelenggaraan praktik kedokteran berupa pelayanan kesehatan secara individual atau disebut pelayanan medik yang didasarkan atas keahliannya dan keterampilan, serta ketelitian. Pasien dan dokter dalam prakterk kesehatan memiliki hubungan yang saling terkait. Hubungan tersebut tidak dapat terlepas dari sebuah perjanjian yang disebut perjanjian terapeutik atau yang disebut transaksi terapeutik. Perjanjian terapeutik adalah perjanjian antara dokter

\footnotetext{
${ }^{5}$ Sri Kusumadewi, dkk, 2009, Informatika Kesehatan, Graha Ilmu dan Rumah Produksi Informatika, Yogyakarta, hlm 41

${ }^{6}$ Erik Tapan, Implementasi telemedicine, Makalah disampaikan dalam Sidang Ilmiah Penjajakan Peluang Aplikasi dan Implementasi Telemedicine dalam Dunia Kedokteran, Pusat Studi Informatika Kedokteran Universitas Gunadarma, Jakarta 10 November 2006

${ }^{7}$ Soegijardjo Soegijoko, Perkembangan Terkini Telemedika dan E Health serta Prospek Aplikasinya di Indonesia, Makalah disampaikan dalam Seminar Nasional Aplikasi Teknologi Informasi 2010 (SNATI 2010) Teknik Informatika, Fakultas Teknologi Industri, Universitas Islam Indonesia (TI FTI UII) di Yogyakarta, 19 Juni 2010

8 Johan Harlan, "Dasar-Dasar Implementasi Telemedicine," Makalah Pusat Studi Informatika Kedokteran Universitas Gunadarma

${ }^{9}$ H. Hendrojono Soewono, 2007, Batas Pertanggung Jawaban Hukum Malpraktik Dokter dalam Transaksi Terapeutik, Srikandi, Surabaya, hlm 3

${ }^{10}$ Soerjono Soekanto, 1987, Pengantar Hukum Kesehatan, Remadja Karya, Bandung, hlm. 29

${ }^{11}$ Sri Fatimahningsih, 2006, Kedudukan Hukum Perawat Dalam Upaya Pelayanan Kesehatan Di Rumah Sakit, Rajawali Press, Jakarta, hlm. 3

${ }^{12}$ Bahder Johan Nasution, 2005, Hukum Kesehatan Pertanggungjawaban Dokter, Jakarta: Rineka Cipta, hlm. 11

${ }^{13}$ Subekti, 1963, Hukum Perjanjian, Jakarta: PT Pembimbing Masa, hlm. 1
} 
dengan pasien, berupa hubungan hukum yang melahirkan hak dan kewajiban bagi kedua belah pihak. Berbeda dengan perjanjian yang dilakukan oleh masyarakat pada umumnya, perjanjian terapeutik memiliki objek dan sifat yang khusus. ${ }^{14}$

Transaksi terapeutik merupakan bagian pokok dari upaya kesehatan, yaitu berupa pemberian pelayanan medik yang didasarkan atas keahliannya dan keterampilan, serta ketelitian, maka tujuannya tidak dapat dilepaskan dari tujuan ilmu kedokteran itu sendiri. Pasal 1 angka 6 Undang-Undang Nomor 36 Tahun 2009 tentang Kesehatan yang berbunyi: "Tenaga Kesehatan adalah setiap orang yang mengabdikan diri dalam bidang kesehatan serta memiliki pengetahuan dan/atau keterampilan melalui pendidikan di bidang kesehatan yang untuk jenis tertentu memerlukan kewenangan untuk melakukan upaya kesehatan."15

Untuk sahnya perjanjian terapeutik sebagaimana perjanjian pada pasal $1320 \mathrm{BW}$ merupakan instrument pokok untuk menguji keabsahan kontrak yang dibuat para pihak. Dalam pasal 1320 BW tersebut terdapat empat syarat yang harus dipenuhi untuk sahnya suatu kontrak, yaitu:

1. Sepakat mereka yang mengikatkan dirinya (de toestemming van degenen die zich verbinden);

2. Kecakapan untuk membuat perikatan (de bekwaamheid om eene verbintenis aan te gaan);

3. Suatu hal tertentu (een bepaald onderwerp);

4. Suatu sebab yang halal atau diperbolehkan (eene geoorloofde oorzaak). ${ }^{16}$

Hubungan terapeutik adalah hubungan yang khusus, karena apabila ada konflik atau sengketa antara penyedia jasa kesehatan dan penerima jasa pelayanan kesehatan, maka masing-masing pihak tunduk pada konsep hukum yang mengaturnya. Karakteristik perikatan dalam transaksi terapeutik adalah Inspanning, ${ }^{17}$ yang berarti bahwa suatu perikatan terapeutik adalah tidak didasarkan pada hasil akhir akan tetapi didasarkan pada upaya yang sungguhsungguh untuk mencapai kesembuhan pasien.

Di dalam transaksi terapeutik, pihak penerima pelayanan medis, adalah pasien. terdiri dari orang dewasa yang cakap untuk bertindak, orang dewasa yang tidak cakap untuk bertindak, yang memerlukan persetujuan dari pengampunya, anak yang berada di bawah umur yang memerlukan persetujuan dari orang tuanya atau walinya. Kecakapan harus datang dari kedua belah pihak yang memberikan pelayanan maupun yang memerlukan pelayanan. ${ }^{18}$ Kalangan dokter harus mempunyai kecakapan yang memadai atau dituntut oleh pasien. Sedangkan dari pihak pasien tentu dituntut orang yang cakap membuat perikatan, yaitu orang dewasa yang waras. Bila lain dari itu tentu harus ada yang mengantar sebagai pendamping pasien. ${ }^{19}$

Disamping kedua asas di atas ada satu faktor utama yang harus dimiliki oleh para pihak yaitu adanya suatu itikad baik dari masing-masing pihak untuk melaksanakan perjanjian.

Objek dari pada perjanjian adalah prestasi. Dalam konteks hukum perdata, prestasi adalah apa yang menjadi kewajiban debitur dan apa yang menjadi hak kreditur. Sesuatu yang dapat dituntut adalah Prestasi sebagaimana diatur dalam Pasal 1234 KUH Perdata, yaitu:

1. Memberikan sesuatu;

2. Berbuat sesuatu; dan

3. Tidak berbuat sesuatu.

Dalam kaitan hubungan dokter dengan pasien prestasi yang diutamakan adalah melakukan suatu perbuatan, baik dalam rangka pencegahan (preventif), penyembuhan (kuratif), pemulihan (rehabilitatif), maupun peningkatan (promotif). ${ }^{20}$

Syarat sebab yang diperbolehkan sebagaimana dimaksud dalam perjanjian terapeutik adalah dimana upaya penyembuhan (terapeutik), tujuan daripada upaya penyembuhan adalah pemeliharaan dan peningkatan kesehatan yang berorientasi atas asas kekeluargaan, mencakup kegiatan peningkatan kualitas kesehatan (promotif), pencegahan penyakit (preventif), penyembuhan penyakit (kuratif), dan pemulihan kesehatan (rehabilitatif). Dengan demikian perikatan yang terjadi adalah dalam bidang pengobatan dan tidak melanggar hukum. ${ }^{21}$ Dalam hal apabila terjadi perikatan yang menyangkut perjanjian teurapeutik namun di dalamnya dilakukan secara melanggar hukum, maka tidak merupakan suatu perbuatan yang halal atau dapat dikategorikan perjanjian tersebut cacat hukum karena tidak memenuhi unsur keempat dalam syarat sahnya perjanjian.

Dokter dan pasien adalah dua subyek hukum yang terkait dalam Hukum Kedokteran. Keduanya membentuk baik hubungan medik maupun hubungan hukum. Hubungan medik dan hubungan hukum antara dokter dan pasien adalah hubungan yang obyeknya pemeliharaan Kesehatan pada umumnya dan pelayanan kesehatan pada khususnya.

Seorang dokter mungkin saja telah bersikap dan berkomunikasi dengan baik, membuat keputusan medik dengan cemerlang dan/atau telah melakukan tindakan diagnostik dan terapi yang sesuai standar, namun kesemuanya tidak akan memiliki arti dalam pembelaannya apabila tidak ada rekam medis yang baik. Rekam medis yang baik adalah rekam medis yang memuat semua informasi yang dibutuhkan, baik yang diperoleh dari pasien, pemikiran dokter, pemeriksaan dan tindakan dokter, komunikasi

\footnotetext{
${ }^{14}$ Bahder Johan Nasution, Loc.cit.

${ }^{15}$ Veronica Komalawati, 2002, Peranan Informed Consent Dalam Transaksi Terapeutik (Persetujuan Dalam Hubungan Dokter dan Pasien), Bandung: PT. Citra Aditya Bakti, hal. 121

${ }^{16}$ Agus Yudha Hernoko, 2010, Hukum Perjanjian Asas Proporsionalitas dalam Kontrak Komersial, Jakarta.

${ }^{17}$ Veronika Komalawati, Op.Cit., Hal. 84

${ }^{18}$ Amri Amir, 1997, Bunga Rampai Hukum Kesehatan, Widya Medik, Jakarta, Hal. 15

${ }^{19} \mathrm{Ibid}$

${ }^{20} \mathrm{Ibid}, \mathrm{hlm} .14$.

${ }^{21}$ Amri Amir. Op.Cit, hlm. 15
} 
antar tenaga medis / kesehatan, informed consent, dan lain-lain, serta informasi lain yang dapat menjadi bukti di kemudian hari yang disusun secara berurutan kronologis. Rekam medis dapat digunakan sebagai alat pembuktian adanya kelalaian medis, namun juga dapat digunakan untuk membuktikan bahwa seluruh proses penanganan dan tindakan medis yang dilakukan dokter dan tenaga kesehatan lainnya sesuai dengan standar profesi dan standar prosedur operasional atau berarti bahwa kelalaian medis tersebut tidak terjadi.

Sekarang ini tuntutan professional terhadap profesi ini makin tinggi. Berita yang menyudutkan serta tudingan bahwa dokter telah melakukan kesalahan di bidang medis bermunculan. Di Negara-negara maju yang lebih dulu mengenal istilah makpraktik medis ini ternyata tuntutan terhadap dokter yang melakukan ketidaklayakan dalam praktek juga tidak surut. Biasanya yang menjadi sasaran terbesar adalah dokter spesialis bedah (ortopedi, plastic dan syaraf), spesialis anestesi serta spesialis kebidanan dan penyakit kandungan. Malpraktik medik terjadi kalau dokter atau orang yang ada di bawah perintahnya dengan sengaja atau karena kelalaian melakukan perbuatan (aktif atau pasif) dalam praktik medik terhadap pasiennya dalam segala tingkatan yang melanggar standar profesi, standar prosedur, atau prinsip-prinsip kedokteran, atau dengan melanggar hukum tanpa wewenang dengan menimbulkan akibat (causal verband) kerugian bagi tubuh, kesehatan fisik, maupun mental dan atau nyawa pasien, dan oleh sebab itu membentuk pertanggungjawaban hukum bagi dokter. Ada beberapa hal yang dapat menyebabkan terjadinya malpraktik, antara lain :

1. Malpraktik karena kesengajaan, misalnya pada kasus-kasus melakukan aborsi tanpa indikasi medis, Euthanasia, membocorkan rahasia kedokteran, tidak melakukan pertolongan pada kasus gawat padahal diketahui bahwa tidak ada orang lain yang bisa menolong, serta memberikan surat keterangan dokter yang tidak benar.

2. memberikan pelayanan medis menurut standar profesi dan standar prosedur operasional;

3. memperoleh informasi yang lengkap dan jujur dari pasien atau keluarganya; dan

4. menerima imbalan jasa.

Herkutanto mengutip dari Word Medical Association Statement on Medical Malpractice yang diadaptasi dari 44th World Medical Assembly Marbela Spain , September 1992 menyebutkan bahwa: “ Malpraktik medis adalah kegagalan dokter untuk memenuhi standar prosedur dalam penanganan pasiennya, adanya ketidak mampuan atau kelalaian, sehingga menimbulkan penyebab langsung adanya kerugian pada pasiennya. ${ }^{22}$

Ada tiga teori yang menyebutkan sumber dari perbuatan malpraktek yaitu: ${ }^{23}$

\section{Teori Pelanggaran Kontrak}

Salah satu teori yang mengatakan bahwa sumber perbuatan malpraktek adalah karena terjadinya pelanggaran kontrak. Ini berprinsip bahwa secara hukum seorang tenaga kesehatan tidak mempunyai kewajiban merawat seseorang bilamana diantara keduanya tidak terdapat suatu hubungan kontrak antara tenaga kesehatan dengan pasien. Hubungan antara tenaga kesehatan dengan pasien baru terjadi apabila telah terjadi kontrak diantara kedua belah pihak tersebut.

Dalam keadaan penderita tidak sadar diri ataupun keadaan gawat darurat misalnya, seorang penderita tidak mungkin memberikan persetujuannya.Apabila terjadi situasi yang demikian ini, maka persetujuan atau kontrak tenaga kesehatan pasien dapat diminta dari pihak ketiga, yaitu keluarga penderita yang bertindak atas nama dan mewakili kepentingan penderita. Apabila hal ini juga tidak mungkin, maka demi kepentingan penderita, menurut perundang-undangan yang berlaku, seorang tenaga kesehatan diwajibkan memberikan pertolongan dengan sebaik-baiknya. Tindakan ini, secara hukum telah dianggap sebagai perwujudan kontrak tenaga kesehatan-pasien.

\section{Teori Perbuatan Yang Disengaja}

Teori kedua yang dapat digunakan oleh pasien sebagai dasar untuk menggugat tenaga kesehatan karena perbuatan malpraktek adalah kesalahan yang dibuat dengan sengaja (intentional tort), yang mengakibatkan seseorang secara fisik mengalami cedera (asssult and battery)

\section{Teori Kelalaian}

Teori ketiga menyebutkan bahwa sumber perbuatan malpraktek adalah kelalaian (negligence). Kelalaian yang menyebabkan sumber perbuatan yang dikategorikan dalam malpraktek ini harus dapat dibuktikan adanya, selain itu kelalaian yang dimaksud harus membuktikan hal yang demikian ini tentu saja bukan merupakan tugas yang mudah bagi aparat penegak hukum.

Kode Etik Kedokteran Indonesia merupakan pedoman bagi dokter Indonesia anggota IDI dalam melaksanakan praktek kedokteran. Tertuang dalam SK PB IDI no 221/PB/A.4/04/2002 tanggal 19 April 2002 tentang penerapan Kode Etik Kedokteran Indonesia. Kode Etik Kedokteran Indonesia pertama kali disusun pada tahun 1969 dalam Musyawarah Kerja Susila Kedokteran Indonesia. Dan sebagai bahan 214 Badamai Law Journal, Vol. 2, Issues 2, Sept rujukan yang dipergunakan pada saat itu adalah Kode Etik Kedokteran Internasional yang telah disempurnakan pada tahun 1968 melalui Muktamar Ikatan Dokter Sedunia ke 22, yang kemudian disempurnakan lagi pada MuKerNas IDI XIII, tahun 1983. Selanjutnya kode etik tersebut

\footnotetext{
${ }^{22}$ Herkutanto, Dimensi Hukum Dalam Pelayanan Kesehatan. Lokakarya Nasional Hukum Dan Etika Kedokteran, Makasar 26-27 Januari 2008. Proceeding. Ikatan Dokter Indonesia Cabang Makasar.

${ }^{23}$ Ninik Maryati, 1998, Malpraktek Kedokteran Dari Segi Hukum Pidana Dan Perdata, PT Bina Aksara, Jakarta, , hlm.44
} 
dituangkan dalam Surat Keputusan Menteri Kesehatan RI Nomor 434/Menkes/SK/X/1983 tenggal 28 Oktober 1983. Kode Etik Kedokteran Indonesia terdiri atas 4 (empat) kewajiban, 2 kewajiban yang dipergunakan dalam penelitian ini yaitu:

1. Kewajiban umum, berupa:

a. Setiap dokter harus menjunjung tinggi, menghayati dan mengamalkan Sumpah Dokter.

b. Seorang dokter harus senantiasa berupaya melaksanakan profesinya sesuai dengan standard profesi yang tertinggi.

c. Dalam melakukan pekerjaan kedokterannya, seorang dokter tidak boleh dipengaruhi oleh sesuatu yang mengakibatkan hilangnya kebebasan dan kemandirian profesi.

d. Setiap dokter harus menghindarkan diri dari perbuatan yang bersifat memuji diri.

e. Tiap perbuatan atau nasehat yang mungkin melemahkan daya tahan psikis maupun fisik hanya diberikan untuk kepentingan dan kebaikan pasien, setelah memperoleh persetujuan pasien.

f. Setiap dokter harus senantiasa berhati hati dalam mengumumkan dan menerapkan setiap penemuan tehnik atau pengobatan baru yang belum diuji kebenarannya dan hal hal yang dapat menimbulkan keresahan masyarakat.

g. Seorang dokter hanya memberi surat keterangan dan pendapat yang telah diperiksa sendiri kebenarannya.

h. Seorang dokter harus, dalam setiappraktek medisnya, memberikan pelayanan medis yang kompeten dengan kebebasan teknis dan moral sepenuhnya, disertai rasa kasih sayang ( compassion ) dan penghormatan atas martabat manusia.

i. Seorang dokter harus bersikap jujur dalam berhubungan dengan pasien dan sejawatnya, dan berupaya untuk mengingatkan sejawatnya yang dia ketahui memiliki kekurangan dalam karakter atau kompetensi, atau yang melakukan penipuan atau penggelapan, dalam menangani pasien.

j. Seorang dokter harus menghormati hak hak pasien, hak hak sejawatnya, dan hak tenaga kesehatan lainnya, dan harus menjaga kepercayaan pasien.

k. Setiap dokter harus senantiasa mengingat akan kewajiban melindungi hidup mahluk insani.

1. Dalam melakukan pekerjaannya seorang dokter harus memperhatikan kepentingan masyarakat dan memperhatikan semua aspek pelayanan kesehatan yang menyeluruh (promotif, preventif, kuratifdan rehabilitatif), baik fisik maupun psiko-sosial, serta berusaha menjadi pendidik dan pengabdi masyarakat yang sebenar benarnya.

m. setiap dokter dalam bekerja sama dengan para pejabat dibidang kesehatan dan bidang lainnya serta masyarakat, harus saling menghormati.

2. Kewajiban dokter terhadap pasien, berupa:

a. Setiap dokter wajib bersikap tulus ikhlas dan mempergunakan segala ilmu dan ketrampilannya untuk kepentingan pasien. Dalam hal ini ia tidak mampu melakukan suatu pemeriksaan atau pengobatan, maka atas persetujuan pasien, ia wajib merujuk pasien kepada dokter yang mempunyai keahlian dalam penyakit tersebut.

b. Setiap dokter harus memberikan kesempatan kepada pasien agar senantiasa dapat berhubungan dengan keluarga dan penasehatnya dalam beribadat dan atau dalam masalah lainnya.

c. Setiap dokter wajib merahasiakan segala sesuatu yang diketahuinya tentang seorang pasien, bahkan juga setelah pasienitu meninggal dunia.

d. Setiap dokter wajib melakukan pertolongan darurat sebagai suatu tugas perikemanusiaan, kecuali bila ia yakin ada orang lain bersedia dan mampu memberikannya.

Tanggung jawab adalah suatu yang mewajibkan seseorang harus menanggung sesuatu jika terjadi hal yang tidak dikehendaki, orang tersebut boleh disalahkan, diperkarakan, dituntut dan sebagainya. ${ }^{24}$ Secara umum prinsip-prinsip tanggung jawab dalam hukum dapat dibedakan:

1. Prinsip tanggung jawab berdasarkan kesalahan (liability based on fault), yaitu prinsip yang menyatakan bahwa seseorang baru dapat dimintakan pertanggungjawabannya secara hukum jika ada unsur kesalahan yang dilakukannya;

2. Prinsip praduga untuk selalu bertanggung jawab (Presumption of liability), yaitu prinsip yang menyatakan tergugat selalu dianggap bertanggung jawab sampai ia dapat membuktikan, bahwa ia tidak bersalah, jadi beban pembuktian ada pada tergugat;

3. Prinsip praduga untuk tidak selalu bertanggung jawab (Presumption of nonliability), yaitu prinsip ini merupakan kebalikan dari prinsip pradugauntuk selalu bertanggung jawab, dimana tergugat selalu dianggap tidak bertanggung jawab sampai dibuktikan, bahwa ia bersalah;

4. Prinsip tanggung jawab mutlak (Strict liability), dalam prinsip ini menetapkan kesalahan tidak sebagai faktor yang menentukan, namun ada pengecualianpengecualian yang memungkinkan untuk dibebaskan dari tanggung jawab, misalnya keadaan force majeur;

5. Prinsip tanggung jawab dengan pembatasan (limitation of liability), dengan adanya prinsip tanggung jawab ini, pelaku usaha tidak boleh secara sepihak menentukan klausula yang merugikan konsumen, termasuk membatasi maksimal tanggung jawabnya. Jika ada pembatasan, maka harus berdasarkan pada perundang- undangan yang berlaku. ${ }^{25}$

\footnotetext{
${ }^{24}$ Peter Salim dan Yenny Salim, Kamus Bahasa Indonesia Kontemporer, hlm. 1538

${ }^{25}$ Shidarta, 2000, Hukum Perlindungan Konsumen Indonesia. PT. Grasindo, Jakarta, hlm. 58
} 


\section{IV.PENUTUP}

\section{A. Kesimpulan}

Berdasarkan pembahasan yang telah peneliti paparkan dalam jurnal ini, dapat diperoleh kesimpulan sebagai berikut

1. Hingga saat ini, belum ada pengaturan yang detail tentang layanan medis berbasis online baik dalam ketentuan perundang-undangan maupun dalam ketentuan kode etik kedokteran. Undang-Undang Nomor 36 Tahun 2009 tentang Kesehatan dan Undang-Undang Nomor 29 Tahun 2004 tentang Praktik Kedokteraan sejauh ini belum dapat dijadikan rujukan atas penyelenggaraan praktik kedokteran dengan menggunakan layanan medis berbasis online. Selanjutnya, Undang-Undang Nomor 11 Tahun 2008 Tentang Informasi dan Transaksi Elektronik juga tidak dapat menjadi rujukan dalam beberapa kasus seperti informed consent ataupun kerahasiaan rekam medis pasien. Dimana rekam medis sendiri ini sifatnya rahasia dan wajib dijaga oleh dokter dan hanya dapat diakses dalam keadaan tertentu dan seizin dengan pasien.

2. Tanggung jawab hukum dokter dalam memberikan pelayanan medis berbasis online adalah tanggung jawab hukum secara perdata, pidana, dan administrasi, sedangkan tanggung jawab profesi akan ditindak lanjuti sesuai dengan prosedur yang ada pada kode etik kedokteran. Seperti penjelasan diatas bahwasanya prosedur pelayanan medis berbasis online ini hanya bersifat jarak jauh dan pastinya tidak akan mendapatkan hasil diagnosis suatu penyakit yang diderita oleh pasien tersebut. Dimana dalam layanan medis berbasis online sendiri dapat terjadinya kesalahan ataupun malpraktik yang terjadi.

\section{B. Saran}

1. Perlu adanya pengaturan undang-undang yang spesifik membahas tentang penggunaan layanan medis berbasis online karena beberapa ketentuan yang telah ada sebelumnya, belum dapat mengatur dan mengikuti perkembangan terhadapat isu hukum atas layanan medis berbasis online.

2. Perlu dan sangat penting sekali diatur mengenai batasan - batasan dalam pelaksanaan pelayanan kesahatan karena layanan medis online ini dapat mengakibatkan hal yang tidak diinginkan seperti kesalahan dalam diagnosis, ataupun kesalahan dalam terapi suatu penyakit pada pasien ataupun bocornya rekam medis pasien tersebut.

\section{DAFTAR PUSTAKA}

\section{A. Buku}

Amir, Amri, 1997, Bunga Rampai Hukum Kesehatan, Widya Medik, Jakarta.

Fatimahningsih, Sri, 2006, Kedudukan Hukum Perawat Dalam Upaya Pelayanan Kesehatan Di Rumah Sakit, Rajawali Press, Jakarta.

Herkutanto, Dimensi Hukum Dalam Pelayanan Kesehatan. Lokakarya Nasional Hukum Dan Etika Kedokteran, Makasar 26-27 Januari 2008. Proceeding. Ikatan Dokter Indonesia Cabang Makasar

Hernoko, Yudha, Agus, 2010, Hukum Perjanjian Asas Proporsionalitas dalam Kontrak Komersial, Jakarta.

Kansil, CST, 1991, Pengantar Hukum Kesehatan Indonesia, Rineka Cipta, Jakarta.

Kusumadewi, Sri, 2009, Informatika Kesehatan, Graha Ilmu dan Rumah Produksi Informatika, Yogyakarta.

Komalawati, Veronica, 2002, Peranan Informed Consent Dalam Transaksi Terapeutik (Persetujuan Dalam Hubungan Dokter dan Pasien), Bandung: PT. Citra Aditya Bakti.

Maryati, Ninik, 1998, Malpraktek Kedokteran Dari Segi Hukum Pidana Dan Perdata, PT Bina Aksara, Jakarta.

Nasution, Johan, Bahder, 2005, Hukum Kesehatan Pertanggungjawaban Dokter, Jakarta: Rineka Cipta.

Salim, Yenny dan Salim, Peter, Kamus Bahasa Indonesia Kontemporer.

Shidarta, 2000, Hukum Perlindungan Konsumen Indonesia. PT. Grasindo, Jakarta

Soekanto, Soerjono, 1987, Pengantar Hukum Kesehatan, Remadja Karya, Bandung.

Subekti, 1963, Hukum Perjanjian, Jakarta: PT Pembimbing Masa.

Soewarno, Hendrojono, H., 2007, Batas Pertanggung Jawaban Hukum Malpraktik Dokter dalam Transaksi Terapeutik, Srikandi, Surabaya.

\section{B. Jurnal}

Harlan, Johan, “Dasar-Dasar Implementasi Telemedicine,” Makalah Pusat Studi Informatika Kedokteran Universitas Gunadarma.

Maramis, Marchel, 2016, Tinjauan Yuridis Terhadap Otopsi Medikolegal Dalam Pemeriksaan Mengenai Sebab-Sebab Kematian, Jurnal Hukum Universitas Sam Ratulangi, J1., Vol.21, No.5, Januari, 2016, Medan.

Soegijoko, Soegijardjo, Perkembangan Terkini Telemedika dan E Health serta Prospek Aplikasinya di Indonesia, Makalah disampaikan dalam Seminar Nasional Aplikasi Teknologi Informasi 2010 (SNATI 2010) Teknik Informatika, Fakultas Teknologi Industri, Universitas Islam Indonesia (TI FTI UII) di Yogyakarta, 19 Juni 2010.

Tapan, Erik, Implementasi telemedicine, Makalah disampaikan dalam Sidang Ilmiah Penjajakan Peluang Aplikasi dan Implementasi Telemedicine dalam Dunia Kedokteran, Pusat Studi Informatika Kedokteran Universitas Gunadarma, Jakarta 10 November 2006.

\section{Peraturan Perundang-undangan}

Kitab Undang-Undang Hukum Perdata (KUHPerdata).

Undang-Undang Nomor 29 Tahun 2004 tentang Praktik Kedokteran.

Undang-Undang Nomor 36 Tahun 2009 Tentang Kesehatan

Undang-Undang Nomor 19 Tahun 2016 Tentang Perubahan Atas Undang-Undang Nomor 11 Tahun 2008 Tentang Informasi dan Transaksi Elektronik

Peraturan Menteri Kesehatan Nomor 269 Tahun 2008 Tentang Rekam Medis

Peraturan Menteri Kesehatan Nomor 20 Tahun 2019 Tentang Penyelenggaraan Pelayanan Telemedicine Antar Pelayanan Fasilitas Kesehatan 